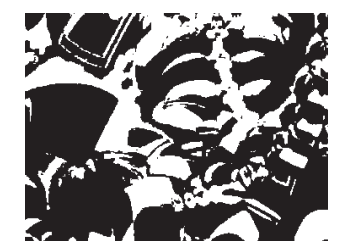

\title{
A SHIFT IN PERCEIVING ORGANISATIONAL METAPHORS AMONG BUSINESS ADMINISTRATION STUDENTS IN AN EU COUNTRY: A WINDOW INTO THE CURRENT THINKING OF FUTURE EMPLOYEES
}

Barbara GRAH, Vlado DIMOVSKI, Judita PETERLIN

Faculty of Economics, Ljubliana

UDK: 005.32

Izvorni znanstveni rad

Primljeno: 17. 12. 2015.

This article aims to offer an insight into which metaphors future employees use to perceive an organisation as a concept. The results of inductive content analysis, based on a sample of 208 business students, show that students offer a varied set of metaphors that are vivid and provide new perspectives. The metaphor of the organisation as a machine and a living organism is still frequently used, although most often an organisation is understood in terms of linkages among social entities. Nevertheless, the ability to comprehend multiple perspectives and use critical judgments is a necessary skill educators must pass on to future generations living in a world characterised by rapid, almost unlimited access to information through the Internet and other media.

Keywords: metaphors, organisation, linkage, change, image

$\triangle \quad$ Barbara Grah, Faculty of Economics, University of Ljubljana, Kardeljeva ploščad 17, 1000 Ljubljana, Slovenia, EU.

E-mail: barbara.grah@ef.uni-li.si

Understanding realities is not only important from the individual but also from the social perspective because it defines how we act. As a result, understanding vital social constructs is extremely important for society. Lakoff and Johnson (1980) 
DRUŠ. ISTRAŽ. ZAGREB GOD. 27 (2018), BR. 1, STR. 133-154

GRAH, B., DIMOVSKI, V., PETERLIN, J.

A SHIFT IN PERCEIVING.. claim that metaphors are far more than just figures of speech since they determine our deeply ingrained mental models, namely, how we see the world, and thus also affect our lives and our daily use of them. The construct of organisation as a term is of particular value in every society, whether in its formal or informal shape, through which people fulfil their goals and perform day-to-day actions, and therefore also live their lives. Daft and Wiginton (1979) even claim metaphors hold powerful meanings for understanding organisational processes. Understanding which metaphors are the most widely used for an organisation is vital, and the metaphors employed are nevertheless also gained through the social processes of learning in which formal education systems play an important role.

Students entering the higher education system now and in the future will have very diverse learning needs. Higher education thus needs to develop in order to provide flexible opportunities for larger and more diverse student cohorts (Hunt, 2011) to successfully enter the labour market. In the European Union, every year several million graduates of social sciences, business and law join the labour market. In 2012, approximately 4.8 million students graduated from tertiary education institutions in the European Union (28 countries) with $34.4 \%$ of them having studied social sciences, business and law (Eurostat, 2015b), making it important to understand how they perceive organisation as a term. In the Slovenian student population, $42 \%$ are male and $58 \%$ are female (Meze, 2014).

Therefore, we aim to provide an insight into understanding the young generation's perceptions of "organisation". The paper's main aim is to examine how business students, who will be trained to professionally deal with organisation during their studies, e.g. starting up a new organisation or managing it, or act in any other business profession roles, understand organisation. Another aim of this study is to establish whether respondents can comprehend the complex meaning of an organisation by understanding several different metaphors or if they only see it through a single perspective, which by definition is always partial. Our research questions are the following: "How do students of business administration understand organisation?" and "Do they have multiple perspectives on metaphors for organisation?"

In addition, answers to our research questions will allow us to answer the call by Morgan (2006), the pioneer of organisational metaphors, who in his latest contribution also acknowledged the network metaphor for an organisation; "Historically, mechanistic and organismic metaphors have dominated the study and practice of organisation and management. It remains to be seen whether the new context and demands of the twenty-first century will transform this" (Morgan, 2006, p. 422). 
DRUŠ. ISTRAŽ. ZAGREB GOD. 27 (2018), BR. 1 STR. 133-154

GRAH, B., DIMOVSKI, V., PETERLIN, J: A SHIFT IN PERCEIVING...
According to Cornelissen, Kafouros, and Lock (2005), an organisation was primarily perceived as a machine or living organism. Due to all the major shifts in society, the question arises whether younger generations, which are entering the labour market, still primarily understand an organisation as a machine and organism. The findings of this study are expected to reflect on contemporary society, and can be used by educators, education system policy makers, as well as other people involved in developing future generations - the society. Our research enhances students' employability according to the definition of ILO (en. International Labour Organization) (Brewer, 2013) which states that employability skills are "portable competencies and qualifications that enhance an individual's capacity to make use of the education and training opportunities available in order to secure and retain decent work, to progress within the enterprise and between jobs, and to cope with changing technology and labour market conditions". By being aware of different perspectives on organisation, students become aware of different, yet partial lenses to comprehend organisation. If teachers equip students with comprehensive frameworks of organisation, they give them skills for the knowledge society, which are major concerns of the European employment policies addressing the Europe 2020 targets (Eurostat, 2015a).

This paper begins by defining metaphors and presents an overview of metaphors previously used for "organisation" as a term. After the methodological section, the findings of a qualitative study of business students are presented, serving as a basis for conclusions and recommendations for the teaching profession in higher education institutions.

\section{THEORETICAL OVERVIEW}

\section{Metaphors}

The word metaphor derives from the Greek words meta meaning 'beyond' and - pherein meaning 'to bear', and stands for going beyond the pure textual meaning of a word. As such, it is used as a substitute for literal or objective definitions (Paparone, 2008). Lakoff and Johnson (Johnson \& Lakoff, 2003; Lakoff \& Johnson, 1980) changed the way we perceive metaphors by claiming metaphors are far more than just manners of speaking.

Metaphors govern our everyday functioning, not only through language but also via our actions and thoughts, as "the essence of metaphor is understanding and experiencing one kind of thing or experience in terms of another" (Lakoff \& Johnson, 1980, p. 455). A metaphor is formed by using a source 
DRUŠ. ISTRAŽ. ZAGREB GOD. 27 (2018), BR. 1, STR. 133-154

GRAH, B., DIMOVSKI, V., PETERLIN, J.

A SHIFT IN PERCEIVING.. domain to understand a target domain. It reveals how a human thinks and acts, even though a human might often be unaware of the metaphors he/she lives by. Lakoff and Johnson (Johnson \& Lakoff, 2003; Lakoff \& Johnson, 1980) further explained that people contribute source domain attributes to the target domain also when unconsciously thinking and talking metaphorically and that a large part of the human conceptual system is metaphorically structured. Furthermore, Johnson and Lakoff (2003) showed that when a group of people understands a certain object through the same metaphor, that metaphor becomes embedded into their way of living and their culture, and can create their reality.

According to the domains-interaction model of metaphor (Cornelissen, 2005; Cornelissen, 2006), the metaphor goes beyond comparison, beyond previously existing similarities. The metaphor is constructed and new meaning is created between the target and source domains, and not extracted from their base meanings. The aptness, selection and adoption of a metaphor is not based on similarities of the source and target domains, but on the combination of within-domains similarity (similarity between source and target concepts - the source concept captures important features of the target concepts) and between-domains distance (semantic distance between source and target domains in metaphor) (Cornelissen, 2006; Cornelissen \& Kafouros, 2008b).

The heuristic value of a metaphor mostly stems from differences and not similarities between source and target domains (Schoeneborn, Blaschke, \& Kaufmann, 2012). Modell (2009) understands metaphor as being crucial to communicating and interpreting unconscious meanings and acts to express neurophysiological processes that embody the bridge between knowledge and feelings, unconsciously categorising emotional experiences by establishing similarities and differences between past and present events. Meaning can therefore be transferred as well as transformed by a metaphor. Nevertheless, metaphors enable people to apprehend understanding (Clark, 2008).

\section{Defining organisation}

Contemporary society is an organisational economy (Simon, 1991). Explicitly defined, in either formal or informal forms, an organisation is a basic unit of human activity. Therefore, how we understand an organisation through the metaphors we use largely determines our realities, how we perceive the world. An organisation can be defined as a system of interrelated human behaviours where humans perform a task that is broken up into several subsystems with each performing their own sub-task, as well as integrated efforts, to achieve 
DRUŠ. ISTRAŽ. ZAGREB GOD. 27 (2018), BR. 1 STR. 133-154

GRAH, B., DIMOVSKI, V., PETERLIN, J.: A SHIFT IN PERCEIVING... effective system performance (Lawrence \& Lorsch, 1967). It can also be seen as a (1) social entity that (2) is goal-directed, (3) designed as a deliberately structured and coordinated activity system, (4) linked to the external environment, where the key elements are people and the relations among them, performing functions to achieve goals (Daft, 2013). An organisation is a consciously coordinated social unit, composed of two or more people, that functions on a relatively continuous basis to achieve a common goal or a set of goals (Robbins \& Judge, 2015, p. 38).

Systems theory focuses on the total work of the organisation and the interrelationships of structure, behaviour and the range of variables within the organisation (Cole \& Kelly, 2015 , p. 96). Systems theory perceives the organisation in terms of its interaction with one another and with the external environment (Cole \& Kelly, 2015, p. 96). Modern systems migrate toward increasing modularity (Schilling, 2000) and virtual collaboration (Šantej \& Penger, 2017). Nevertheless, organisation scholars (Ahrne, Brunsson, \& Seidl, 2016) have also turned away from organisation over the past decades to address phenomena such as institutions or networks.

Complete understanding of an organisation as a system in terms of configuration of subsystems allows prescribing more appropriate organisational designs and managerial systems, since organisation theory should serve as the foundation for more effective management practice (Kast \& Rosenzweig, 1972, p. 447). General systems theory rejected the traditional closed-system, mechanistic view of social organisation. As emphasised by Kast and Rosenzweig, (1972) it started rather with the organismic views of von Bertalanffy; thus, many of the characteristics are relevant to the living organism. General systems theory understands the organisation as a collection of interrelated subsystems (Kast \& Rosenzweig, 1972, p. 452), therefore, it is essential to be able to use different metaphors, which are always partial, when defining an organisation.

\section{Metaphors used for an organisation}

A well-known work on the metaphors people use to understand an organisation is Morgan's (2006) "Images of organization", with the constructionist perspective on theorising on organisation (Cornelissen \& Kafouros, 2008b). In this work, Morgan (2006) explained eight metaphors used for an organisation, which form the basis for developing organisational theories. Morgan (2006) analysed (1) machines; (2) organisms; (3) brains; (4) cultures; (5) political systems; (6) psychic prisons; (7) flux and transformation; and (8) instruments of domination. In addition, he initiated that changes in society might 
DRUŠ. ISTRAŽ. ZAGREB GOD. 27 (2018), BR. 1, STR. 133-154

GRAH, B., DIMOVSKI, V. PETERLIN, J.

A SHIFT IN PERCEIVING.. call for a new metaphor for an organisation, namely network (Morgan, 2006), stating, "all theories of organisation and management are based on implicit images or metaphors that lead us to see, understand, and manage organization in distinctive, yet partial ways" (Morgan, 2006, p. 4). No matter how good a metaphor is, it always creates distortion since the source and target domains are not the same. Furthermore, metaphors are also always partial and incomplete, showing only one side of the object, although metaphors frequently to reinforce each other by overcoming the limitations of another (Morgan, 2006).

In addition, Cornelissen et al. (2005) performed a study on metaphors used for organisation, limiting their research to top management and organisation journals from 1993 to 2003. Cornelissen et al. (2005) identify ten different metaphors used for an organisation - machine, animate being, culture, warfare, system, linkage, family, symbolism, space, and architecture - with the results showing that organisation was most often perceived as a machine or animate being.

Nevertheless, Tsoukas (1991) highlighted two polar roles of metaphors in theorising on organisational science: the first pole emphasising that metaphors allow different insights and focus on various aspects of complex organisation phenomena (Tsoukas, 1991) and the second pole, where "metaphors are deemed as initially inevitable but eventually detrimental to theoretical development due, mainly, to their imprecision and low conceptual content" (Tsoukas, 1991, p. 566). Tsoukas (1991, p. 567) claimed that "usage of metaphorical language in organisational science can be encouraged in the pursuit of literal language", as metaphorical and literal languages are complementary. Cornelissen and Kafouros (2008b) showed that a metaphor's ability to advance and clarify theorising on organisation depends on: (1) the degree to which it captures multiple salient features of organisation; and (2) how easy it is to understand it.

\section{THE METHOD: CONTENT ANALYSIS}

The common approach to researching metaphors is to list them by performing content analysis and quantifying qualitative data (Cornelissen et al., 2005). However, to answer our research questions: "How do students of business administration understand organisation?", "Do they have multiple perspectives on metaphors for organisation?", and to really understand how the young generation understands organisation, and their narratives, deeper understanding was needed requiring contextually rich data to be collected and presented. 
DRUŠ. ISTRAŽ. ZAGREB GOD. 27 (2018), BR. 1 STR. 133-154

GRAH, B., DIMOVSKI, V., PETERLIN, J:

A SHIFT IN PERCEIVING.. when wishing to refer to an organisation, and provide an explanation for their choice(s), namely the context. This allowed the researchers a deeper understanding of the different perspectives of the respondents' answers since words often have more than one meaning.

Narratives are developed in the socio-cultural context in which the narrator lives so the purpose of the narrative analysis is to make sense of both the narrative and socio-cultural context. Parts of the narratives are metaphors we have studied in the higher education environment. In the spotlight are the interpretation and analysis, which hold the true research value (Thomas, 2011). Joint content analysis of the explanations by the authors of this paper was deemed the most appropriate method for analysing the collected responses, aiming to detect the assigned metaphor meaning, which might sometimes be hidden behind the metaphor title itself. Content analysis seeks to determine concepts and theoretical formulations and is therefore part of the interpretation (Penger, 2006).

Cornelissen, Oswick, Christensen, and Phillips (2008) call for greater attention to methodological issues in identifying and analysing metaphors. Tsoukas (1991) proposed a methodology for developing metaphors to offer scientific knowledge regarding organisational processes. In this respect, the qualitative aspect of the research is focused on identifying different perspectives respondents use for organisation. We are interested in learning which perspectives are most often used, and whether they disclose more than one perspective per organisation. Understanding complex issues, such as organisation, from just one perspective could be very dangerous for a society in a world where almost all information required is accessible in real time. Therefore, we also conduct a two-part analysis; first, inductive Phase 1 through the students' wording, and Phase 2 where we placed it within Morgan's (2006) expanded framework.

\section{Sample and units of analysis}

A total of 208 undergraduate students (103 females, 97 males and 8 not revealing their gender) in the 2014/15 academic year of the Faculty of Economics, University of Ljubljana, Slovenia (hereafter FELU), participated in the study. The questionnaire was distributed during different management courses. It was open-ended and contained one main question asking students to name and explain the metaphors they use for an organisation. The study has two different units of analysis; the first being the metaphor named and contextualised as provided by a respondent and the second is a student as a respondent. 


\section{Analysis procedure and data processing}

The answers were collected by e-mail or submitted written papers. For the analysis, the MS Office and NVivo 10 software tools were used.

\section{Phase 1: Inductive descriptive method}

Students' perceptions of an organisation were analysed using the inductive descriptive method. It enables a rich presentation of students' comprehension of an organisation. Proof citations (Langley, 2012) of the identified phenomenon reveal the depth of their thinking. The authors also ran a word frequency query in NVivo, based solely on the provided names of metaphors.

\section{Phase 2: Classification by categories}

To quantify the qualitative data, the authors performed an independent content analysis. Where there were different opinions on the context, a discussion followed in order to reach consensus. Not only the metaphor title, but also its explanation was analysed and arranged in a previously agreed classification according to the enumeration criteria.

As Cornelissen and Kaforus (2008a, p. 957) argue, complex metaphors used for organisation consist of "smaller primary metaphors or metaphorical parts, which form the atomic components of the molecular structure of complex meta-

(1) TABLE 1

Classification of organisational metaphors phorical thought". In line with Morgan (2006), we classified the answers on the first level into context metaphors, and on the second level into primary metaphors, as shown in Table 1.

Context metaphors Primary metaphors

Machine

Living organisms

Brains

Culture

Political systems

Psychic prison

Flux and transformation Instruments of domination

Linkages

Attitudes
Morgan's framework

Automatisation and controlled system; Mechanical parts; Productivity

Resources needed for functioning - inputs, outputs; Structure Animal; Darwinism; Human; Life-cycle; Plant Human brains; Learning; Learning organisation Communication, exchanging information; Shared systems of meaning Power plays and conflicts Group think Change; Chaos; Circularity of positive and negative flows Bossy relationship; Non-sustainable; Sustainable

Inductively built categories

Animal and vegetarian linkages; Human family;

Social linkages - collaboration; Sports; Wholeness

Creativity and innovation; Discipline, hard work and passion; Strategy

Source: G. Morgan, Images of organization, 2006. 
DRUŠ. ISTRAŽ. ZAGREB GOD. 27 (2018), BR. 1 STR. 133-154

GRAH, B., DIMOVSKI, V., PETERLIN, J:

A SHIFT IN PERCEIVING..

(1) TABLE 2

Content analysis

examples

\section{Recording unit and enumeration criteria for Phase 2}

The named and contextualised metaphor was taken as the recording unit. This allowed the researchers to understand the metaphor provided and to quantify the qualitative data by its classification. Before quantifying the data, strict rules were agreed on: (1) the primary and complex metaphors used; (2) one named metaphor could consist of more than one complex metaphor, depending on its context, where each complex metaphor was identified; (3) one named metaphor under one complex metaphor could have more than one primary metaphor, although the analysis was conducted on the level of complex metaphors and here a specific complex metaphor is counted only once when analysing metaphors; (4) when analysing the number of different metaphors the students provided, one complex metaphor could be counted a maximum of once, although the student might name several different metaphors for the same complex metaphor; and (5) the answers were classified according to the explanation provided, not only its title as exemplified in Table 2.

\begin{tabular}{|c|c|c|}
\hline Quote & Criteria & Comment \\
\hline $\begin{array}{l}\text { Quote 1: Organisation as good as bread } \\
\text { "If we say to someone that he is as good as } \\
\text { bread, that is usually a positive connotation. } \\
\text { This man likes to help a fellow man, his } \\
\text { positive outlook is shared with the other and } \\
\text { the same applies to the organisation. If the } \\
\text { organisation is as good as bread, this could } \\
\text { mean that the organisation helps humanity. } \\
\text { Examples of an organisation as good as } \\
\text { bread include charities". }\end{array}$ & 5 & $\begin{array}{l}\text { If we only analysed by the title of the } \\
\text { metaphor, it would not fit into any } \\
\text { defined category. Yet in-depth research } \\
\text { and triangulation of the content analysis } \\
\text { revealed the metaphor used here is } \\
\text { sustainability. }\end{array}$ \\
\hline $\begin{array}{l}\text { Quote 2: A family journey } \\
\text { "When a family sets off on a longer } \\
\text { journey, there is much quarrelling: what to } \\
\text { bring along, how much luggage, food etc. } \\
\text { Therefore, it is wise to initially set goals, } \\
\text { plans, how, when and where we will go. } \\
\text { This allows us to quickly and effectively } \\
\text { achieve the objectives we want to achieve. } \\
\text { Thus, in my eyes I see the organisation } \\
\text { as a family journey, as it requires good } \\
\text { organisation and cooperation between } \\
\text { people in order to jointly achieve the } \\
\text { desired results". }\end{array}$ & 5 & $\begin{array}{l}\text { Based on analysing the context, we } \\
\text { classified this metaphor under attitudes } \\
\text { category strategy, instead of family. }\end{array}$ \\
\hline $\begin{array}{l}\text { Quote 3: Aggressive, free and noble } \\
\text { like a white eagle } \\
\text { "The company must be aggressive towards } \\
\text { the external market, easily penetrating } \\
\text { through innovation and market competition. } \\
\text { Available to new innovations and ways to }\end{array}$ & 3,2 & $\begin{array}{l}\text { The metaphor used fits within the } \\
\text { animal and Darwinism primary } \\
\text { metaphors, but was only counted once } \\
\text { as an organism complex metaphor. In } \\
\text { addition, it was classified in the attitu- } \\
\text { des category creativity and innovation. }\end{array}$ \\
\hline
\end{tabular}

(continued) 
(1) TABLE 2 (continued)

\begin{tabular}{|c|c|c|}
\hline Quote & Criteria & Comment \\
\hline \multicolumn{3}{|l|}{$\begin{array}{l}\text { new aspects that can improve business. } \\
\text { Kind to their customers and simply daring } \\
\text { towards their competitors (innovation/ } \\
\text { price/other cost for normal survival). } \\
\text { Unique products should be more valuable } \\
\text { than others due to the company name } \\
\text { and brand, holding certain standards". }\end{array}$} \\
\hline $\begin{array}{l}\text { Quote 4: Coordinated like a pack } \\
\text { of wolves when attacking victims } \\
\text { "The company must be coordinated in all four } \\
\text { management functions so that information } \\
\text { is very quickly accessible and transferred } \\
\text { from one end to the other within the organisation. } \\
\text { Quick reactions to market imbalance and } \\
\text { new problems, solutions to common problems, } \\
\text { mutual assistance and informing. Joint, } \\
\text { progressive penetration into new markets } \\
\text { with innovations and mutual trust. Task division } \\
\text { and a common goal". }\end{array}$ & $4,3,2$ & $\begin{array}{l}\text { The metaphor was classified under } \\
\text { animal linkages within the linkages } \\
\text { complex metaphor, Darwinism within } \\
\text { the organism complex metaphor and } \\
\text { creativity and innovation within } \\
\text { attitudes metaphors. } \\
\text { Since quote } 3 \text { and } 4 \text { are by the same } \\
\text { author, they were both counted together } \\
\text { only once as an organism metaphor, and } \\
\text { once as a creativity and innovation } \\
\text { attitudes metaphor when the unit of } \\
\text { analysis was the student. }\end{array}$ \\
\hline $\begin{array}{l}\text { Quote 5: A fight } \\
\text { "I see a company as a fight for survival } \\
\text { because without it we do not have any source } \\
\text { of income for paying for the indispensable } \\
\text { necessities of life. Without money we cannot } \\
\text { pay for food, water and other costs necessary } \\
\text { for normal survival. Inside the company, } \\
\text { we need to demonstrate all our knowledge } \\
\text { and learn new things in order to fight for } \\
\text { survival within the company". }\end{array}$ & 2 & $\begin{array}{l}\text { Based on the named metaphor and its } \\
\text { explanation, we analysed it as } \\
\text { consisting of more than one complex } \\
\text { metaphor, i.e. Darwinism and brains. }\end{array}$ \\
\hline
\end{tabular}

\section{RESULTS}

The 208 respondents named and contextualised a total of 630 metaphors. The majority of students provided three metaphors (total of 164 students; Figure 1), with an average of 3.03 metaphors named per student.

In our sample, 22 students identified 1 complex metaphor, 60 students identified 2 complex metaphors, 77 students identified 3 complex metaphors, 34 students identified 4 complex metaphors and 12 students identified 5 complex metaphors. Only 3 respondents identified more than 5 complex metaphors, where 8 was the maximum (Figure 2). On average, students each named 2.83 complex metaphors.

The single most used word provided by students when naming the metaphors was machine, flowed by family, organism, living, team, human, working, fight and network, as presented in Figure 3. 
DRUŠ. ISTRAŽ. ZAGREB GOD. 27 (2018), BR. 1 STR. 133-154

GRAH, B., DIMOVSKI, V., PETERLIN, J.:

A SHIFT IN PERCEIVING...

FIGURE 1

Number of metaphors per students

FIGURE 2

Number of complex metaphors per students

- FIGURE 3

Naming metaphors word frequency usages
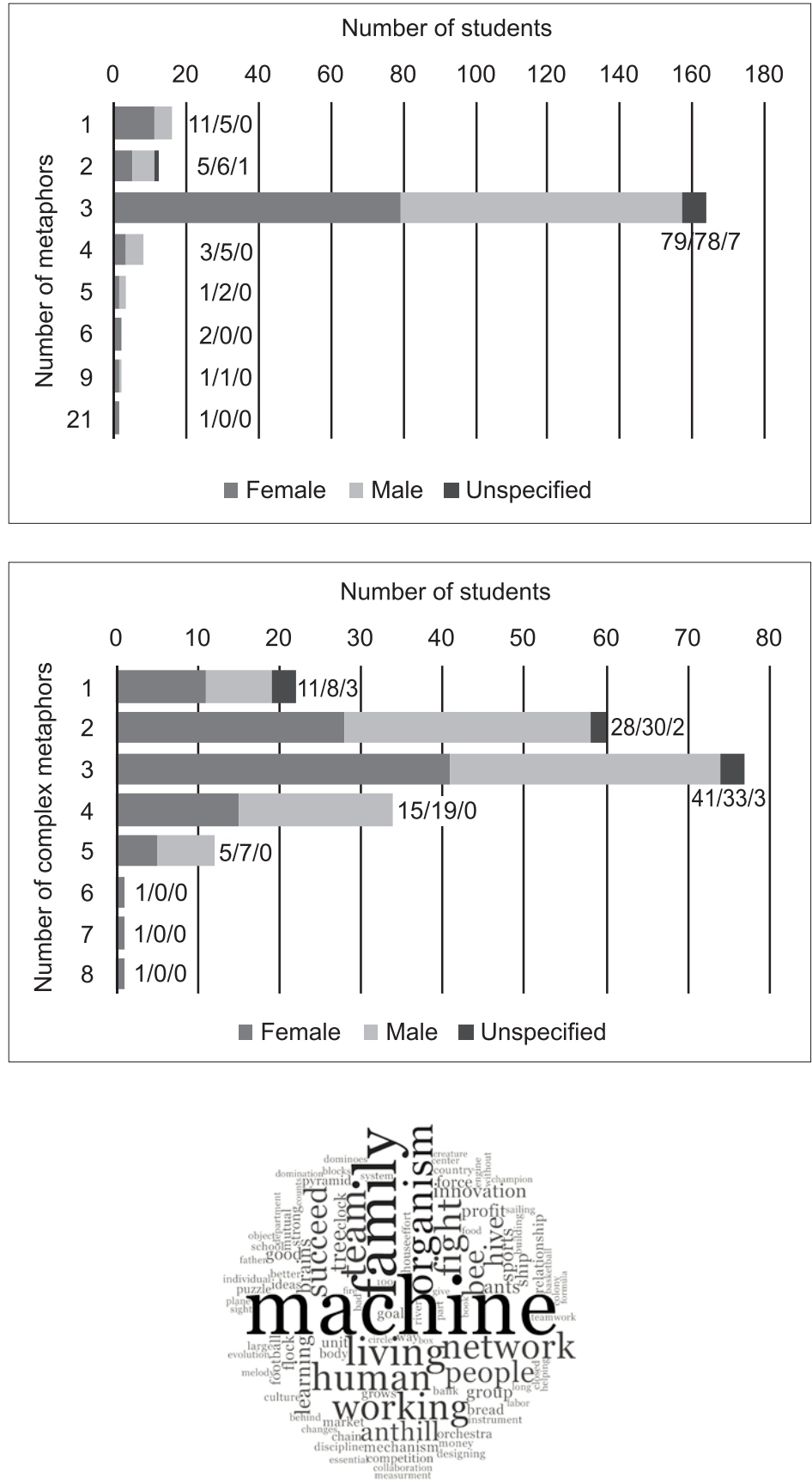

Although the word machine is the single most frequently used word, it is important to note that it was by far the word most often used denouncing the machine complex metaphor, while e.g. the linkages metaphor was identified with several different words, for example: "family", "team", "net- 
DRUŠ. ISTRAŽ. ZAGREB GOD. 27 (2018), BR. 1, STR. 133-154

GRAH, B., DIMOVSKI, V. PETERLIN, J.:

A SHIFT IN PERCEIVING..

(1) TABLE 3

Metaphor

identification

frequency work", "beehive", "anthill", and others. To offer the readers a rich insight of the inductively derived metaphors, we provide a sample of additional interesting metaphors, such as "tree", "puzzle", "circle", "chameleon", "persistent as a snail", "dough", "endless river", "self-supporting bridge", "solar system", "fish in water", "phoenix", "necklace production", "one", "melting pot", "sailing team", "aircraft carrier", "choir", "pharaoh with slaves" etc.

Further analysis of the data took into consideration the full description of the metaphor besides the metaphor name itself. The most frequently expressed metaphor for an organisation (Table 3) among the students was Linkages, followed by Machine, Organism, Flux and transformation, Instruments of domination, Brains, Culture, Political system, Psychic prison. A special group of metaphors was identified as attitudes metaphors that did not fit in any pre-identified metaphor group, and therefore provides an avenue for future research.

\begin{tabular}{|c|c|c|c|}
\hline \multicolumn{2}{|l|}{ Complex metaphors } & \multicolumn{2}{|l|}{ Primary metaphors } \\
\hline Machine & 128 & $\begin{array}{l}\text { Automatisation and controlled system } \\
\text { Mechanical parts } \\
\text { Productivity } \\
\text { Resources needed for functioning - inputs, outputs } \\
\text { Structure }\end{array}$ & $\begin{array}{l}15 \\
51 \\
11 \\
23 \\
37\end{array}$ \\
\hline Living organisms & 122 & $\begin{array}{l}\text { Animal } \\
\text { Darwinism } \\
\text { Human } \\
\text { Life-cycle } \\
\text { Plant }\end{array}$ & $\begin{array}{l}11 \\
39 \\
27 \\
41 \\
18\end{array}$ \\
\hline Brains & 41 & $\begin{array}{l}\text { Human brains } \\
\text { Learning } \\
\text { Learning organisation }\end{array}$ & $\begin{array}{r}10 \\
26 \\
6\end{array}$ \\
\hline Culture & 34 & $\begin{array}{l}\text { Communication, exchanging information } \\
\text { Shared systems of meaning }\end{array}$ & $\begin{array}{l}13 \\
21\end{array}$ \\
\hline Political systems & 17 & Power plays and conflicts & 17 \\
\hline Psychic prison & 2 & Group think & 2 \\
\hline Flux and transformation & 52 & $\begin{array}{l}\text { Change } \\
\text { Chaos } \\
\text { Circularity of positive and negative flows }\end{array}$ & $\begin{array}{l}14 \\
17 \\
22\end{array}$ \\
\hline Instruments of domination & 50 & $\begin{array}{l}\text { Bossy relationship } \\
\text { Non-sustainable } \\
\text { Sustainable }\end{array}$ & $\begin{array}{r}22 \\
9 \\
20\end{array}$ \\
\hline Linkages & 199 & $\begin{array}{l}\text { Animal and vegetarian linkages } \\
\text { Human family } \\
\text { Social linkages - collaboration } \\
\text { Sports } \\
\text { Wholeness }\end{array}$ & $\begin{array}{l}48 \\
30 \\
94 \\
20 \\
11\end{array}$ \\
\hline Attitudes & 117 & $\begin{array}{l}\text { Creativity and innovation } \\
\text { Discipline, hard work and passion } \\
\text { Strategy }\end{array}$ & $\begin{array}{l}22 \\
45 \\
58\end{array}$ \\
\hline
\end{tabular}


DRUŠ. ISTRAŽ. ZAGREB GOD. 27 (2018), BR. 1 STR. 133-154

GRAH, B., DIMOVSKI, V., PETERLIN, J.:

A SHIFT IN PERCEIVING..

FIGURE 4

Complex metaphors

identification

frequency
Each of the 630 metaphors could be grouped into more than one complex metaphor based on the description of the metaphor; therefore (Figure 4) 762 metaphors are presented. Each complex metaphor was counted only once, even if the same metaphor was in two or more primary metaphors within a certain complex metaphor. The linkage metaphor was the most frequently identified complex metaphor, followed by machine and organism complex metaphors. Words hold different meanings in different contexts and for research purposes we provided the most elaborate explanation possible of the metaphor meaning.

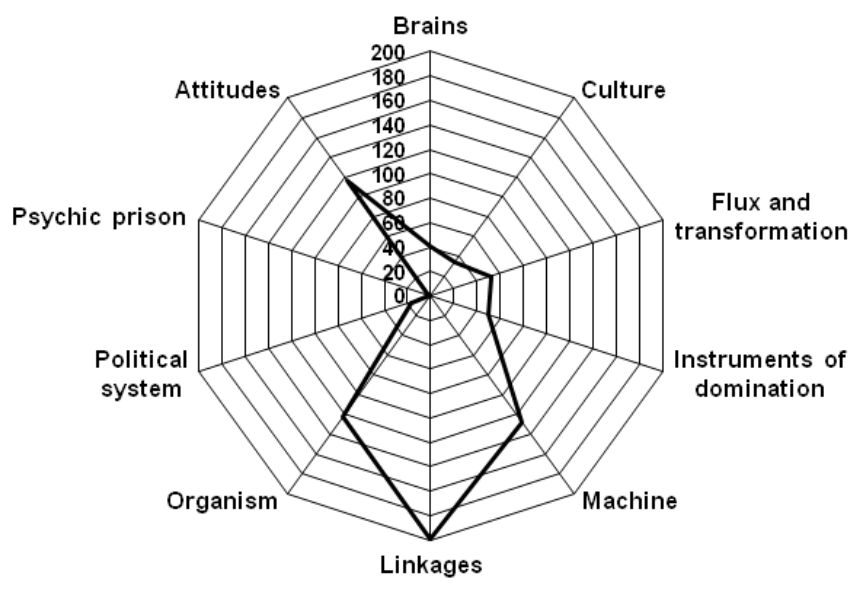

Figure 5 is a visual representation of the students' perceptions of an organisation by gender. Based on our qualitative data analysis in the NVivo software, we identified several metaphors under the complex metaphors. The codes were identified based on reading the names and description of the organisational metaphors the respondents provided. E.g., in the case of the complex metaphor machine, organisation was perceived in terms of mechanical parts 51 times, 37 times as a structure and 23 times as inputs and outputs needed for the machine to function.

In order to present the richness and vividness of the students' creativity in thinking about an organisation, we provide additional proof citations:

Organisation can be seen as a family, emphasising linkages (Quote 6): "Colleagues in the company spend together 8-10 hours a day. Interpersonal relationships, like in the family, grow among them. [...] Family quarrels are quite normal, but in closely related families they do not lead to family disintegration, but may help clarify the conflict situations and connect the family more closely." 


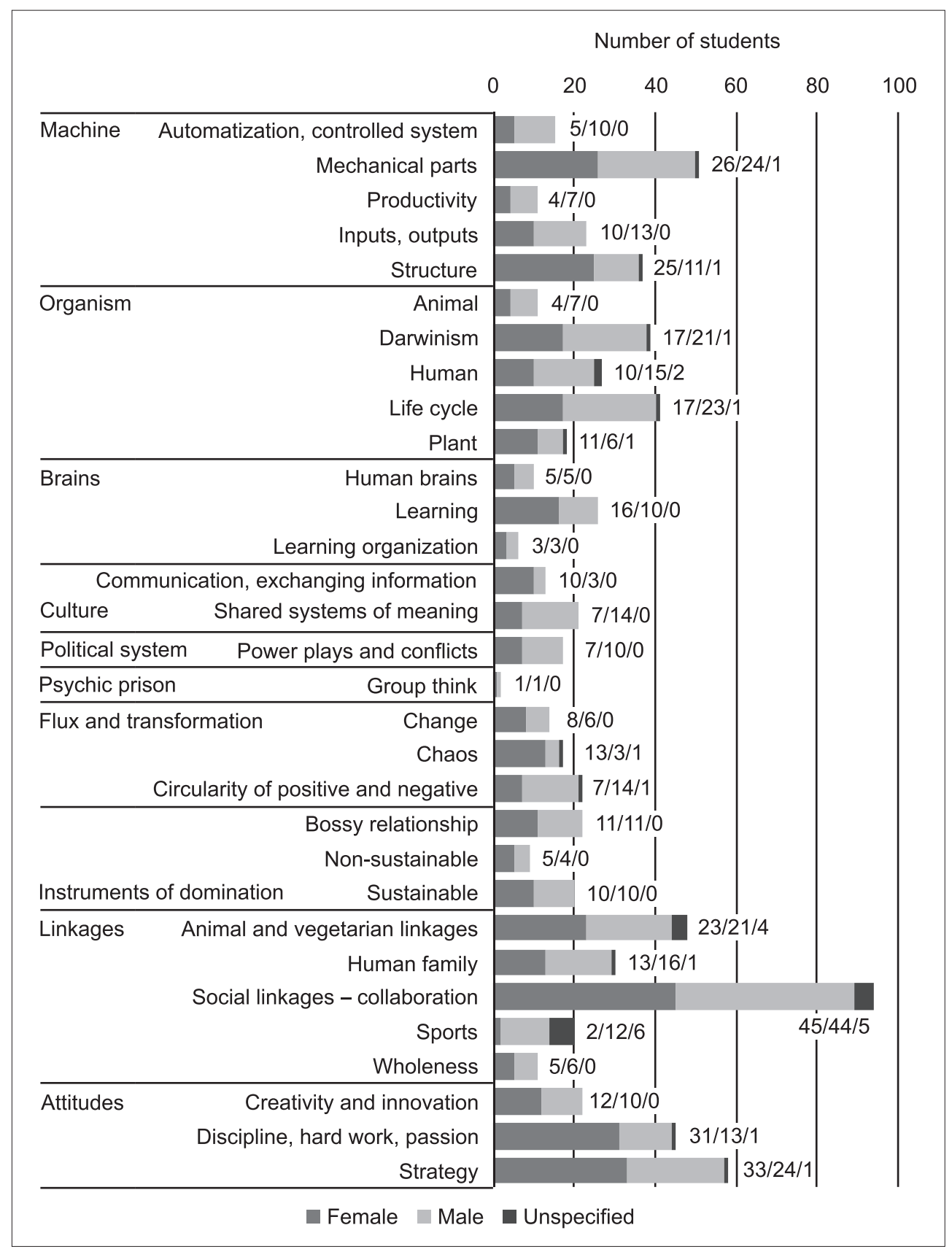

i FIGURE 5

Frequency of complex and primary metaphors as identified by students' gender
This student referred to the reliability of the connections (Quote 7): "A spider's web is composed of thicker and stronger threads, which are a kind of holders for the thin threads that are interwoven between the thicker ones. If we tear only one string, the web may collapse. It is the same way in the organisation. If only one member lets you down or there is a distur- 
DRUŠ. ISTRAŽ. ZAGREB GOD. 27 (2018), BR. 1 STR. 133-154

GRAH, B., DIMOVSKI, V., PETERLIN, J: A SHIFT IN PERCEIVING... bance in the functioning of the company, the whole organisation collapses. However, if the spider knits the web with additional 'holders', the web will not break or the damage will be reduced and the spider will be able to correct it. It is similar in the organisation. If you have an additional plan, many people will not even know that you had a problem - that one of the strings was broken, as you will have a new holder. That other string is another plan - a back-up plan."

This student perceives an organisation's vital role in terms of (Quote 8): "In the company, organisation is the framework. Without good organisation we do not achieve the desired results. The consequences of poor organisation are mistakes and divisions among the departments. Therefore, I imagine an organisation as the human skeleton because no organisation would be successful, nor achieve its objectives without it. Just like a human being could not stand without the skeleton."

The following student sees an organisation in terms of ecosystems - Darwinism (Quote 9): "We know that fish live in the lake. Each of them must eat to survive. Thus, the lake contains fish which feed on insects they find on the water surface or at the bottom of the lake, while others are predators and eat other fish for survival. [...] The lake is a metaphor for the market in which companies are fish. Some companies have found a way to survive, whether it be through a good product or a new service. Large companies are predators which for their existence or greater market share need to buy smaller companies and 'feed' in this way and dominate the market".

In the following explanation of an organisation, we can see its key characteristic, namely adaptability (Quote 10): "I see an organisation as being flexible as a chameleon. The chameleon is an animal which when catching prey, in order to remain as invisible as possible, will change its body colour depending on the environment in which it is located. [...] Companies today need to adjust to the market in order to become successful, just like a chameleon when chasing its prey. In many cases, for businesses to survive in the market it is necessary to change overnight their business orientation and adapt to the market and customers. Also, companies which have this capability or 'power' can nowadays successfully survive in the market and generate profits".

The following student sees an organisation as Frankenstein (Quote 11): "With time, organisations can 'magically come to life' and give the impression they have their own independent life, internal inertia and own will. It seems like they are fighting for their survival independently of people. A set of systematic mechanisms which enhance organisational efficiency independently of the efficiency of its people and that are established by people to maintain and further en- 
DRUŠ. ISTRAŽ. ZAGREB GOD. 27 (2018), BR. 1, STR. 133-154

GRAH, B., DIMOVSKI, V. PETERLIN, J.:

A SHIFT IN PERCEIVING.. hance the organisation can also lead to unethical behaviour in the name of organisational survival. It is sometimes difficult to determine subjective individual responsibility as organisational systematic rules are built over long periods by various actors".

\section{DISCUSSION AND CONCLUSION}

Metaphors are not just figures of speech, but should be understood as mental models embodied in human cognition and culture, determining realities (Lakoff \& Johnson, 1980). How people perceive organisation is important as the majority of the human lifetime is usually spent in different kinds of organisation. This study focused on the younger generation of business students to offer an insight into how they understand organisation, and into their awareness of multiple perspectives on the issue. In the future, today's business students will be involved in managing an organisation and performing other vital organisational functions. The results reveal that, on average, students provided 2.83 complex metaphors, showing their awareness of and ability to see an object of study, and therefore their vivid realities, through multiple perspectives.

It is crucially important in a period characterised by unlimited information provided by the Internet and other modern technologies, for such students to be able to search for other alternatives, including through formal education, and to not be satisfied with the first option offered. This finding is in line with Howe (2007), who stressed that narrowing down a complex semantic and behavioural field to a single noun distorts analysis. The world should be understood within a larger, complex context, not just through one metaphor, underpinning the fact that several different metaphors might exist for the same object and that metaphors have different knowledge functions (Tsoukas, 1991). Another crucial step for students is to apply critical judgements to identify which perspective to take into consideration in certain situations, and it is up to educators to teach and equip them with both key abilities.

Regarding the content of the metaphors used, the organisation as linkages was the most frequently used metaphor. This finding agrees with modern, 21st century social and business trends emphasising social media networks, the importance of networking and the latest organisational theories on collaboration, platform strategies and building ecosystems. It shows that students most often see an organisation as entailing different kinds of linkages, where members collaborate to achieve common goals - whether using the human family, animal groups, team sports or other forms of social entities to 
DRUŠ. ISTRAŽ. ZAGREB GOD. 27 (2018), BR. 1 STR. 133-154

GRAH, B., DIMOVSKI, V., PETERLIN, J: A SHIFT IN PERCEIVING... stress the collaboration. This finding is valuable for different reasons. First, society is constantly developing over time, clearly pointing to the importance of online social entities in a new world of collaboration and communication (Cheung, Chiu, \& Lee, 2011). New technologies alter our ways of living, societies and all dimensions of our world (Kovačević, 2015), and thus affect how we understand an organisation.

Our findings identify the shift in focus away from the machine view of the organisation, which is in line with the latest insights in the organisation theory field that emphasise collaboration (Fjeldstad, Snow, Miles, \& Lettl, 2012; Miles, Miles, \& Snow, 2005), platform and ecosystem building (Gawer \& Cusumano, 2008; Yonatany, 2013), and dealing with the disruptive changes an organisation faces, especially in the technology segment. As McCourt (1997) argues, a new metaphor leads to new, creative understandings, although metaphors should not be considered the foundations for building theories, but as a useful analytical tool. It is important to note that the role of metaphors in organisation theory development should not be confused with formal theory testing and empirical research, but as "a precursor to more formal theory and research" (Cornelissen, 2005, p. 752).

This study adds to other research into metaphors used for an organisation, such as (Cornelissen et al., 2005; Morgan, 2006) and others. The findings of this study indicate that the new setting of the 21st century is transforming perceptions of the organisation, yet organisation as a machine and organisation as an organism continue to be frequently used metaphors. Cornelissen et al. (2005) identify linkage and family metaphors, yet according to their study they are not used as often.

Practical implications emphasise the changes in the society that academics, educators and practitioners need to be aware of. The younger generation of students perceives the world and their realities through their own eyes. This enhances the understanding of the organisation as linkages, where collaboration - not competition or cooperation - are most often used. It offers educators a chance to understand the world of younger generations through their eyes, apart from showing them other perspectives. In addition, it is essential that, for achieving consensus across the organisation, each business student can understand multiple perspectives (Kast \& Rosenzweig, 1972) and discuss as well as justify their stands. Nevertheless, the findings also reveal the students' lack of practical long-term work experience during their studies as most of them could not identify organisation as a political system or psychic prison, which usually requires greater time to be noticed among the hidden layers of organisation in its positive or negative context. 
DRUŠ. ISTRAŽ. ZAGREB GOD. 27 (2018), BR. 1, STR. 133-154

GRAH, B., DIMOVSKI, V. PETERLIN, J.

A SHIFT IN PERCEIVING.
The authors observe that, apart from being able to observe multiple perspectives and critically judge them, students need genuine work experiences to upgrade the learned theory with actual, hands-on, real-life case examples to successfully enter the labour market and become active citizens in society. As a practical implication, we strongly recommend that students acquire practical work experience in an organisational setting through internships, which were obligatory in Slovenia up until recently. We advise students to proactively search for such opportunities and any governmental policy in support of building a responsible well-educated, critical thinking workforce, and teachers to encourage them in that direction.

During our data analysis, we also identified attitudes metaphors; namely "Creativity and innovation"; "Discipline, hard work and passion" as well as "Strategy". This indicates that future employees are creative and value hard work, strategy, discipline and innovation, while also aspiring for clear directions.

The paper has some limitations. The main limitation has its roots in linguistic research, emphasising the researchers' role during the analysis, since organisational metaphors influence the perception of the writers' communication role and the rhetorical choices (Suchan, 1995). In order to minimise this limitation, the authors conducted an independent content analysis and where there were different opinions on classifying the metaphors and metaphorical explanations, a consensus was sought, allowing each metaphor to be grouped in more than one classification.

The second limitation refers to the sample used as the analysis focused on business administration students at FELU. Our research focus was not on statistical generalisation, but on deeper insights into how students perceive organisation and whether they are capable of observing multiple perspectives.

Nevertheless, the reader's attention also needs to be drawn to the issue of language as the students' replies were in the Slovenian language and the graphic presentation of the NVivo classification of identified metaphors (Figure 3) and proof citations provided could contain some losses in translation as the data were translated for that presentation from Slovenian into English to allow understanding of the language originally used.

The questionnaire form enabled three or more metaphors to be identified. However, we should stress that three brackets were generated and participants could have added a fourth or later ones. We note that not many students chose the option of adding new brackets to the questionnaire form. However, one key finding of this study is not the exact average number of metaphors provided, but that students are aware of and have multiple perspectives on organisation. 


\section{ACKNOWLEDGEMENTS}

We thank anonymous reviewers for helpful comments on earlier drafts of this paper.

\section{REFERENCES}

Ahrne, G., Brunsson, N., \& Seidl, D. (2016). Resurrecting organization by going beyond organizations. European Management Journal, 34(2), 93-101. https://doi.org/10.1016/j.emj.2016.02.003

Brewer, L. (2013). Enhancing youth employability: What? Why? and How? Guide to core work skills. Availabe at http://www.ilo.org/skills/pubs/ WCMS_213452/lang--en/index.htm

Cheung, C. M., Chiu, P.-Y., \& Lee, M. K. (2011). Online social networks: Why do students use Facebook? Computers in Human Behavior, 27(4), 1337-1343. https://doi.org/10.1016/j.chb.2010.07.028

Clark, K. M. (2008). Metaphors, frames, and embodied cognition: Tools for understanding our understanding. Journal of the Indiana Academy of the Social Sciences, 12, 125-138.

Cole, G. A., \& Kelly, P. (2015). Management theory and practice. Australia: Cengage Learning.

Cornelissen, J. P. (2005). Beyond compare: Metaphor in organization theory. Academy of Management Review, 30(4), 751-764. https://doi.org/ 10.5465/AMR.2005.18378876

Cornelissen, J. P. (2006). Metaphor in organization theory: Progress and the past. Academy of Management Review, 31(2), 485-488. https://doi. org/10.5465/AMR.2006.20208700

Cornelissen, J. P., \& Kafouros, M. (2008a). The emergent organization: Primary and complex metaphors in theorizing about organizations. Organization studies, 29(7), 957-978. https://doi.org/10.1111/ j.1467-8551.2007.00550.x

Cornelissen, J. P., \& Kafouros, M. (2008b). Metaphors and theory building in organization theory: What determines the impact of a metaphor on theory? British Journal of Management, 19(4), 365-379.

Cornelissen, J. P., Kafouros, M., \& Lock, A. R. (2005). Metaphorical images of organization: How organizational researchers develop and select organizational metaphors. Human Relations, 58(12), 1545-1578. https://doi.org/10.1177/0018726705061317

Cornelissen, J. P., Oswick, C., Christensen, L. T., \& Phillips, N. (2008). Metaphor in organizational research: Context, modalities and implications for research - Introduction. Organization Studies, 29(1), 7-22. https://doi.org/10.1177/0170840607086634

Daft, R. L. (2013). Understanding the theory $\mathcal{E}$ design of organizations (11th edition - international edition ed.). Canada: Cengage Learning. Daft, R. L., \& Wiginton, J. C. (1979). Language and organization. Academy of Management Review, 4(2), 179-191.

Eurostat (2015a). Europe 2020 Indicators. Available at http://ec.europa. eu/eurostat/web/europe-2020-indicators 
DRUŠ. ISTRAŽ. ZAGREB GOD. 27 (2018), BR. 1, STR. 133-154

GRAH, B., DIMOVSKI, V., PETERLIN, J.

A SHIFT IN PERCEIVING..
Eurostat (2015b). Tertiary education statistics. Available at http://ec. europa.eu/eurostat/statistics-explained/index.php/Tertiary_education_ statistics

Fjeldstad, Ø. D., Snow, C. C., Miles, R. E., \& Lettl, C. (2012). The architecture of collaboration. Strategic Management Journal, 33(6), 734-750. https://doi.org/10.1002/smj.1968

Gawer, A., \& Cusumano, M. A. (2008). How companies become platform leaders. MIT Sloan Management Review, 49(2), 27-35.

Howe, J. (2007). Argument is argument: An essay on conceptual metaphor and verbal dispute. Metaphor and Symbol, 23(1), 1-23. https://doi. org/10.1080/10926480701723516

Hunt, C. (2011). National strategy for higher education to 2030 Report (D. o. E. a. Skills, Trans.) (pp. 134). Dublin: Government publications office. Johnson, M., \& Lakoff, G. (2003). Metaphors we live by. University of Chicago.

Kast, F. E., \& Rosenzweig, J. E. (1972). General systems theory: Applications for organization and management. Academy of Management Journal, 15(4), 447-465.

Kovačević, S. (2015). Eric Schmidt, Jared Cohen: Novo digitalno doba. Nove tehnologije mijenjaju ljude, države, ali i kako ćemo živjeti i poslovati [The new digital age: Transforming nations, businesses, and our lives]. Društvena istraživanja, 24(2), 306-310.

Lakoff, G., \& Johnson, M. (1980). Conceptual metaphor in everyday language. The Journal of Philosophy, 77(8), 453-486. https://doi.org/10. $2307 / 2025464$

Langley, A. (2012). Doing and publishing qualitative research. Helsinki: EGOS.

Lawrence, P. R., \& Lorsch, J. W. (1967). Differentiation and integration in complex organizations. Administrative Science Quarterly, 12(1), 1-47. https://doi.org/10.2307/2391211

McCourt, W. (1997). Discussion note: Using metaphors to understand and to change organizations: A Critique of Gareth Morgan's approach. Organization Studies, 18(3), 511-522. https://doi.org/10.11 77/017084069701800307

Meze, M. (2014). Mednarodni dan študentov 2014. [International students' day 2014]. Available at http://www.stat.si/StatWeb/glavnanavi gacija/podatki/prikazistaronovico IdNovice $=6643$

Miles, R. E., Miles, G., \& Snow, C. C. (2005). Collaborative entrepreneurship: How communities of networked firms use continuous innovation to create economic wealth. Standford, California: Stanford University Press.

Modell, A. H. (2009). Metaphor - The bridge between feelings and knowledge. Psychoanalytic Inquiry, 29(1), 6-11. https://doi.org/10.1080/ 07351690802246890

Morgan, G. (2006). Images of organization. Thousand Oaks: Sage Publications.

Paparone, C. R. (2008). On metaphors we are led by reflection. Military Review, 88(6), 55. 
DRUŠ. ISTRAŽ. ZAGREB GOD. 27 (2018), BR. 1 STR. 133-154

GRAH, B., DIMOVSKI, V., PETERLIN, J:

A SHIFT IN PERCEIVING...
Penger, S. (2006). Učeča se organizacija in oblikovanje pozitivne organizacijske identitete: študija primera slovenskega podjetja [Learning organization and design of positive organizational identity: Case study of Slovene company]. Ljubljana: Faculty of Economics.

Robbins, S. P., \& Judge, T. A. (2015). Organizational behavior. Boston: Pearson.

Schilling, M. A. (2000). Toward a general modular systems theory and its application to interfirm product modularity. Academy of Management Review, 25(2), 312-334.

Schoeneborn, D., Blaschke, S., \& Kaufmann, I. M. (2012). Recontextualizing anthropomorphic metaphors in organization studies: The pathology of organizational insomnia. Journal of Management Inquiry, 22(4), 435-450. https://doi.org/10.1177/1056492612448463

Simon, H. A. (1991). Organisations and markets. Journal of Economic Perspectives, 5(2), 25-44. https://doi.org/10.1257/jep.5.2.25

Suchan, J. (1995). The influence of organizational metaphors on writers' communication roles and stylistic choices. Journal of Business Communication, 32(1), 7-29. https://doi.org/10.1177/002194369503200101

Šantej, A., \&Penger, S. (2017). Konceptualni model povezave e-vodenja in identitete virtualnega tima: mediacijski vpliv zaznave raznolikosti in moderacijski vpliv sodobne komunikacijske tehnologije. [Conceptual model of connecting e-leadership and identity of the virtual team: Mediation effect of diversity perception and moderation effect of the contemporary communication technology]. Economic and Business Review, 19, 45-71.

Thomas, G. (2011). How to do your case study: A guide for students and researchers. London: Sage Publications, Inc.

Tsoukas, H. (1991). The missing link: A transformational view of metaphors in organizational science. Academy of Management Review, 16(3), 566-585.

Yonatany, M. (2013). A model of the platform-ecosystem organizational form. Journal of Organization Design, 2(2), 54-58. https://doi.org/ 10.7146/jod.7267

\section{Promjena metaforičke percepcije pojma organizacije kod studenata poslovne ekonomije u zemlii EU-a: uvid u aktualna mišljenja budućih zaposlenika}

Barbara GRAH, Vlado DIMOVSKI, Judita PETERLIN Ekonomski fakultet, Ljubliana

Cili ovoga rada je prikazati metafore koje mlađe generacije koriste u percipiranju organizacije kao pojma. Rezultati kvalitativnog istraživanja, odnosno induktivne analize sadržaja temeljene na uzorku od 208 studenata poslovne 
DRUŠ. ISTRAŽ. ZAGREB GOD. 27 (2018), BR. 1, STR. 133-154

GRAH, B., DIMOVSKI, V., PETERLIN, J.:

A SHIFT IN PERCEIVING.. ekonomije pokazuju da studenti koriste različite živopisne metafore koje otvaraju nove perspektive. Metafora percepcije organizacije kao stroja i živog organizma još uvijek je u upotrebi, iako se sve češće organizacije zamišliaju i kao mreže. Pored toga, i obaveza je nastavnika da s vještinom razumijevanja različitih perspektiva i korištenja ključnih procjena upoznaju buduće generacije koje žive u svijetu brzih, gotovo neograničenih pristupa informacijama putem interneta i drugih medija.

Ključne riječi: metafore, organizacija, mreže, promjena, imidž

\section{(c) (i) ()ㅇ}

Međunarodna licenca / International License:

Creative Commons Attribution-NonCommercial-NoDerivatives 4.0. 